\title{
Primary Cutaneous B-Cell/T-Cell (Non- MF/SS) Lymphoma M1 TNM Finding v8
}

National Cancer Institute

\section{Source}

National Cancer Institute. Primary Cutaneous B-Cell/T-Cell (Non-MF/SS) Lymphoma M1

TNM Finding v8. NCI Thesaurus. Code C141375.

Extracutaneous non-lymph node disease present. (from AJCC 8th Ed.) 